Article

\title{
Horse Manure Management by Commercial and Old-Order Amish Equine Operators: Economic and Conservation Implications
}

\author{
Justin Dijak, Laura McCann * and Caroline Brock $(1)$ \\ Division of Applied Social Sciences, University of Missouri, 200 Mumford Hall, Columbia, MO 65211-6200, USA; \\ dijakj@missouri.edu (J.D.); brockcc@missouri.edu (C.B.) \\ * Correspondence: mccannl@missouri.edu
}

Received: 1 July 2020; Accepted: 19 October 2020; Published: 21 October 2020

check for updates

\begin{abstract}
Horse operations may produce high amounts of manure per acre/ha and be less aware of recommended manure management practices than livestock farmers, leading to negative environmental impacts. This study compared the manure management practices of two populations of horse owners in the USA state of Missouri, commercial horse operations and an Old-Order Amish community, using data from a 2019 mail survey with a 50\% response rate. In commercial operations, manure was more likely to be piled rather than spread directly on fields, which was the Amish practice. The Amish were more likely to use manure for crop production, to indicate that was why they had not explored markets for manure, and to test soil for nutrients. Regression results for factors affecting previous sales/transfers of manure or compost showed that selling was more likely for commercial operations, female operators, and those who had composted manure. Compared to respondents who agreed that manure management had an impact on water quality, those who did not know or were neutral about that statement were more likely to have sold manure. While both groups can improve manure management and are underserved by traditional agricultural information channels, educational efforts should be tailored to their different circumstances.
\end{abstract}

Keywords: Amish; equine; horse; manure management; value-added; water quality

\section{Introduction}

Manure is a source of nutrients for crops, but also has a variety of negative environmental consequences, including impacts on surface water and groundwater quality, local air quality, and climate change. Sustainable utilization of this resource is therefore crucial [1]. The most recent scientific findings on these environmental problems and options for the sustainable utilization of manure as a natural resource are discussed in a recent book published by the American Society of Agronomy and the Soil Science Society of America [2]. This study examines horse manure management, which exhibits many of the same environmental problems as manure from other species [3], but from a social science perspective.

The overall equine population in the United States (USA) decreased between 2007 and 2012 according to the Census of Agriculture [4]. Generally, equines (primarily horses) are kept for pleasure, farming, or equine businesses. In-depth surveys of operations with more than five equids by USDA-APHIS found that the percentage of equids used for pleasure was similar in 1998 and 2015 (46.1\% and $47.2 \%$, respectively), while the percentage used for farm/ranch work increased $(18.7 \%$ versus $25.0 \%$ ). Small operations (5-9 equids) accounted for the majority of operations during this period, but accounted for a smaller percentage of total equids; in 2015, they represented $67.3 \%$ of operations and $32.1 \%$ of equids. Large operations (over 20 equids) were more likely to have a primary 
function of boarding/training, breeding, or being a riding stable than small operations or those with 10-19 equids [5]. Equine operations thus tend to be diverse in both their activities and their size. However, it is not clear if Amish equine owners were delineated or even included in the USA equine survey (as explained in more depth later, the Amish are a Christian group that has value-based prohibitions against personal ownership and use of certain technologies, such as cars, as well as tractors for field work). For example, when discussing the primary use of equines, transportation was not even listed as an option [5], and the Amish are the main population who would use horses for transportation in the US. However, other data sources indicate that Amish equine operator numbers are growing, since all Amish own horses for local transportation, and their population is doubling every 20 years [6].

These distinct types of operations may have different goals as well as different levels of knowledge regarding the environmental impacts of their operations. In general, equine operations are neglected regarding education and outreach efforts about conservation practices compared to other types of livestock farming [7]. One of the environmental concerns around equines is manure management [7]. The types of environmental impacts of horse manure on air and water quality, their sources, and recommended management practices to reduce these impacts were reviewed by Westendorf et al. [3]. As with other types of manure, excess nutrients and pathogens can degrade water quality [8]. For example, Kleinman et al. [9] indicate that animal manure is a major contributor to phosphorous pollution in the Chesapeake Bay watershed, and horses represent $11 \%$ of animal units in the watershed (one animal unit represents $453.6 \mathrm{~kg}$ liveweight). However, appropriate manure management also presents an opportunity to recycle nutrients back to the soil and to improve organic matter and other soil characteristics valued by farmers [10]. Historically, this occurred in integrated crop-livestock operations. The benefits of manure as a soil amendment also provide the opportunity to create a value-added product for agricultural and residential uses. Horse manure can be composted, which reduces the volume of waste by $40-70 \%$, and horse manure and bedding can potentially have ideal nitrogen/carbon ratios for composting [11] (while beyond the scope of this research, feedstuffs used, the type and quantity of bedding products, and the intensity of horse manure management can affect the quality of the manure products, including the nitrogen/carbon ratio [3,12]).

The existing research on horse manure management practices in the USA usually focuses on small-scale operations or recreational horses kept in confined and pastured settings [3,7]. While this focus is important given the large number of operations where horses are kept for personal recreational use and the environmental impacts associated with them, their motivations may differ from those of equine businesses. Commercial equine operations derive the majority of their income from equine training, boarding, breeding, and sales [13], and may have less knowledge of the use of manure for agricultural production. The Amish are another group that is distinct in that they use horses in their agricultural enterprises and value manure as a soil amendment.

There are also geographic limitations to previous studies on horse manure management, which have focused on the Mid-Atlantic [14], Indiana, and Kentucky [7,13]; only one of these studies discussed Amish horse operators. However, Missouri has the seventh largest number of horses in the USA [4], and no surveys relating to horse manure have been conducted. Missouri also has the seventh highest population of Amish people in the USA [15].

This study was a pioneering effort to compare horse manure management practices among commercial equine operations and Amish communities, as well as their current activities and attitudes regarding value-added horse manure products. This research examined the characteristics of these operations, information sources, and manure management practices, as well as the importance each group places on manure as a soil amendment. Previous research indicated that there is often a disconnection between extension educators and horse farm operators with respect to environmental management issues, as most education efforts seem to be focused on horse management and well-being rather than manure management [7]. Westendorf et al. [3] indicate that equine facility managers in the USA are less aware of soil fertility and nutrient management issues, have less contact with conservation professionals, and face unique challenges compared to farmers. Understanding the knowledge levels 
and decision-making processes of these underserved groups with different motivations and structural considerations is important in order to design targeted educational programs to improve horse manure management and sustainability.

This study also examined the current situation regarding sales of horse manure by these two groups, as well as the potential for new uses and new markets for their horses' manure. More specifically, this research explored some of the barriers to the creation of a value-added manure product, such as access to equipment and current knowledge about composting practices. Manure transfers may also improve water quality if the source operation has excess nutrients relative to agronomic requirements [16].

The research questions are as follows:

1. How do commercial equine operations and Old-Order Amish differ in the characteristics of the operators, their access to equipment for manure management and composting, and their production systems?

2. How is horse manure used and what kinds of manure management practices are implemented in these operations?

3. To what extent are these operators currently selling their manure and what are the barriers to value-added products, such as composted manure?

4. What factors affect the sale of manure products?

It was hypothesized that while manure may be an under-utilized resource in both types of operations, the Amish are more likely to understand and appreciate manure's value as a nutrient source and soil amendment and to use it on their own farms or provide it to neighbors for crop production. In addition, there may be technological barriers for these conservative, Old-Order Amish to pursue value-added manure products for sale. It was hypothesized that commercial horse operations would be more interested in sales and transfers of manure due to their lesser integration with crop production, and they would thus have lower awareness of the nutrient and soil amendment benefits of the manure. It was also hypothesized that higher-value manure products, such as compost, would be more likely to be marketed.

\section{Background}

The trend of specialization in USA agriculture has meant that there are fewer integrated crop-livestock farming systems [17]. This implies that livestock manure is less likely to be seen as a nutrient source and soil amendment and more likely to be seen as a waste product, which has implications for efficient use of manure and water quality $[1,16,18,19]$. This view of manure as a waste product rather than a resource is especially likely among commercial equine operations for several reasons. This section examines the characteristics of this group, followed by those of Amish farmers.

\subsection{Commercial Equine Operations}

For a variety of reasons, commercial equine operations may have issues with manure management. Horse operations use many of the same agricultural inputs (hay, grains, straw, and various other bedding materials) that livestock and dairy producers use; however, they purchase the majority of them rather than relying on crop production. The managers of these operations may, therefore, be less aware of agricultural information sources, less knowledgeable about crop production, and, thus, less knowledgeable about manure as a resource than typical livestock producers in rural areas. Previous research indicates that equine managers are not well connected to organizations that may address larger-scale farm management issues like manure management and its environmental impacts [7]. Many of these enterprises are managed by women who do not have agricultural backgrounds, which means that they are more likely to be overlooked by extension professionals [7]. Owners of many equine operations also have substantial off-farm income, and previous research on 
livestock farmers in the USA's Midwest has found that those with more off-farm income are less likely to adopt manure management practices, such as manure testing [16].

Commercial equine training and boarding operations may house a substantial number of horses that produce manure, which can have ecological and economic implications. Due to the reliance on revenue generated by instruction and training fees, commercial equine operations are usually located near urban and suburban areas, which means higher land values [20]. These operations thus tend to have more intensive equine management and smaller acreages [3]. Extension professionals surveyed by Perry-Hill and Prokopy [7] indicated that a major problem in Kentucky and Indiana was that there were too many horses on too few hectares. In New Jersey, only about one fourth of equine farms that spread manure had more than 8.1 hectares of land [14]. Ali et al. [16] found that livestock density (animal units per unit of surface area, multiple species) was negatively associated with the adoption of manure testing in Iowa and Missouri, perhaps since nutrients were not limiting for crop production. Commercial equine operations are typically too small to be subject to USA water quality regulations, which are relevant for farms with more than 1000 animal units, which implies that they may be less motivated to manage the manure effectively for conservation and soil quality purposes.

In addition to environmental implications, there may be an unrealized economic opportunity for horse managers to sell composted manure as a soil amendment. For example, compost from horse manure has long been used in mushroom production [3]. One problem with livestock manure in general that limits marketability is the higher water content and, thus, higher transportation costs for a given amount of nutrients [16]. Buyers of manure also have preferences by animal species; Norwood et al. [21] found a preference for dairy versus swine manure. There is evidence of equine manure being marketed as a value-added soil amendment. One equine facility in Washington stopped paying for waste disposal and instead began selling compost at $23 \mathrm{USD} / \mathrm{cubic}$ meter, and they recovered their investment in composting technology in three years [22]. However, there may be economies of scale and access to markets that make composting more feasible for some equine operations than others.

\subsection{Amish Operations}

The Old-Order Amish are a Christian group formed out of the Anabaptist movement in the Protestant reformation. They maintain distinct guidelines around technology (e.g., restricting individual car ownership, hence the reliance on horses) to maintain key values such as community, family, and a strong work ethic. All Old-Order Amish own and utilize horses for local transportation, and some also use horses for plowing and harvesting operations. While not all Amish in the USA are farmers, those who move to more rural areas for affordable land and property tax rates, such as in Missouri, are more likely to be involved in farming as part of their economic portfolio. Amish farms tend to be small, which is due in part to their reliance on horses for traction as well their desire to live in close proximity to each other $[23,24]$.

For Amish farmers, manure represents a valuable input for crop production as part of a diversified livelihood strategy, so they may be more motivated to manage manure as a nutrient source than commercial equine operations. The Amish have a long history of utilizing manure for innovative soil fertility practices $[7,25]$, although they may also use commercial fertilizers [26]. While using both commercial fertilizers and manure is not unique to the Amish, people often assume that they produce organically [26].

They tend to have more diversified farms; earlier research found that Amish dairy farmers are also growing vegetables, which was very uncommon for similar non-Amish dairy farms [27]. In these farming systems, outputs from one enterprise can be used as inputs in another, rather than purchasing inputs such as fertilizer or feedstuffs for horses. Given their smaller farms, the Amish tend to intensively farm the land they do have, and to focus more on crops like vegetables, which are labor-intensive. Missouri, in particular, has a sizable group of Amish farmers producing vegetables, as indicated by the nine Amish produce auctions in the state. Vegetables have high nutrient requirements, which may provide an incentive for utilizing manure effectively. Given the integrated nature of their communities 
and their operations, the Amish may be more able to realize the potential of horse manure or composted manure as a nutrient source and soil amendment.

However, horse manure can be a source of controversy for local communities [28] as well as a contributor to water quality issues, especially if these Amish farmers also own larger livestock operations. Relying on horse-drawn equipment may limit how far the manure is spread [29]. Previous research indicates that conservation awareness around manure management may be lower for Amish farmers than non-Amish ones, and they are not as familiar with organizations that could assist with manure management decisions [30,31], which is similar to commercial equine operations. There may also be less time for Amish to invest in conservation efforts given that many also have non-farming occupations [32], again similar to commercial operations. The Old-Order Amish also typically complete their formal education after the eighth grade (i.e., after eight years of schooling) and can be harder to reach for extension and conservation agents than other farmers [7], especially as the internet is not a useful outlet [33]. Social networks for the Amish are highly integrated and overlapping, considering that the Amish may attend church, go to school, and attend other meetings with many of the same families, which may limit the exchange of information with non-Amish farmers.

Given the descriptions of these two populations, they are expected to differ in their manure management practices. In particular, the Old-Order Amish of Clark, Missouri are expected to be more likely to have integrated crop-livestock systems than commercial horse operations, and thus have more on-farm uses for the manure. Well over half $(57 \%)$ of the households in Clark are involved in an agricultural enterprise as part of their economic portfolio [34]. In addition, given the greater density of horses in commercial operations, they may have manure in excess of crop or pasture requirements, and may thus be more interested in sales or transfers of manure products. The Amish may have less access to manure management machinery, which will negatively affect their likelihood of selling manure products compared to commercial operations.

\section{Data and Methods}

In January and February of 2019, a mail survey of commercial equine operators in Missouri and of farmers from an Old-Order Amish settlement in near Clark, Missouri was implemented. A mail version of the survey was chosen rather than an internet-based survey, which would have been inappropriate for the Amish. The Amish are much more likely to read something that comes in the mail [31]. A mailing list of commercial equine operators was compiled using the commercial facility locator features of equestrian organizations in the state of Missouri. These organizations were the Missouri Horse Shows Association, the United States Equestrian Federation, the American Quarter Horse Association, and Equine Now.com. The Clark settlement is one of the largest and oldest communities in Missouri, started in 1953 and consisting of 10 church districts (which consist of 100-125 people). A mailing list was compiled using all entries in the Amish of Missouri 2016 Directory for the settlement of Clark [34]. A combined list was created that included the population of 161 commercial equine operations in Missouri and 172 members of the Clark settlement for a total of 333 operations.

A paper mail survey was developed and implemented using modifications of the Dillman method [35]. The seven-page, 49-question survey obtained information about the overall operation and detailed information about horse manure management. The question format was primarily closed-ended, with some fill-in-the-blank questions, e.g., numbers of horses in each size category. The questions were related to operation attributes, current manure management practices, agricultural production, equipment and labor used for manure, experience with manure as a value-added product, marketing manure, barriers to composting and sales, and attitudes about water quality and soil conservation, and the survey ended with demographic questions. The reminder postcard, cover letters, and surveys were approved by the University of Missouri Institutional Review Board. The survey packet consisted of a cover letter, the survey, and a self-addressed return envelope. The cover letters were signed by hand and the packets were mailed using stamps. The surveys were color-coded to distinguish Amish from commercial operations. Reminder postcards were sent after three weeks, and a 
second survey mailing was sent three weeks after the postcard. One hundred seventy surveys were returned, indicating a $50.9 \%$ response rate after correcting for undeliverable surveys or people who did not have any horses.

The survey data were modified to create variables for the analyses. Detailed explanations are provided for variables used in the regressions (In surveys, it is recommended to have closed-ended rather than open-ended response options and to have categories for sensitive continuous variables, such as age and education [35], which affect the statistical analysis; categorical or dummy variables are used with a designated base category to which the other categories are compared). Over $30 \%$ of the Amish respondents left the open-ended gender question blank. Given that the names to whom the Amish surveys were sent were exclusively male, as well as the patriarchal nature of the Amish community, the blank gender responses were changed to male. The total number of animal unit equivalents (AUE) on the farm/operation was calculated based on the data on equine numbers in various weight ranges, following Manske [36]. The AUE was determined using $226.8 \mathrm{~kg}$ for small horses and ponies, $499 \mathrm{~kg}$ for light horses, and $771.1 \mathrm{~kg}$ for heavy or draft horses [4]. The AUE was calculated for each weight category and then summed for each respondent across all three categories, and the natural log of this number was used in the regression. Four response options for current manure management practices were: "spread fresh over fields", "composted", "piled", or "piled then later spread over fields." The base category, which included the most responses, was "spread fresh over fields".

A dummy variable for manure management time was constructed by using $0-3 \mathrm{~h} /$ week as the base, since there were substantial numbers across both types of operations, and the other time categories were combined into $>3 \mathrm{~h}$ as the categorical variable. Their level of agreement with the statement "Manure management practices affect water quality" was also included as a dummy variable with "agree"/"strongly agree" combined as the base category, with dummy variables for "disagree"|"strongly disagree", "neither agree nor disagree", and "I do not know". Another dummy variable was created by combining questions about testing soil, manure, or compost for nutrient content into one question, with the base being no nutrient testing. Agricultural producers can use manure to improve crop production, which would provide an alternative use for selling manure or compost, so participants were asked whether they "produced and marketed crops in the previous year".

Participants were asked about equipment used for manure management. Farm machinery can significantly reduce the labor required to turn and move large amounts of manure and compost. For the regression of only commercial operators, the machinery was also grouped by functions related to manure management to form categorical variables. The base category was managers that use manure spreaders, which was the most common type of equipment found in the survey. The categorical variables were "no use of machinery" and "tractors with buckets, bobcats, and skid loaders", i.e., equipment that will only pile, turn, and load manure. This subset has access to the complete complement of equipment needed for handling piles of manure or compost, but no access to equipment to apply manure or compost to fields.

Larger commercial equine operations often only use barn staff that are "hired by the primary operator" to perform manure management duties. These operations may have more intensive manure management practices than smaller operations, where horse owners or boarders are responsible for manure management duties. Manure management in a paid or professional setting may thus be predictive of manure or compost sales. Operations with only hired staff for this task formed the categorical variable, while operations that included boarders, owners, or family members were used as the base.

Descriptive statistics were examined for a wide variety of questions in order to compare characteristics of operators and operations, manure management practices, and conservation attitudes of commercial equine operations and Amish farms. Statistical comparison of the means of the variables was conducted using two-tailed t-statistics. Before further analysis, a correlation coefficient matrix was examined to identify multicollinearity among variables (data available upon request). 
To rigorously examine determinants of manure transfers, bivariate logistic regression was conducted using the $\mathrm{R}$ programming language. Logistic regression is a method used for categorical dependent variables. Previous experience with marketing manure or value-added manure products was used as the dichotomous dependent variable. Pseudo-R squared and the Akaike information criterion (AIC) were used to diagnose model fit and explanatory power of the model.

For the combined group regression, 160 observations were used due to missing data for some respondents. Thirty-one of these respondents had sold manure or compost; the base of the bivariate logistic regression was those who had not sold a manure product. Percentage of income from horses could not be used, nor could crop hectares or variables incorporating it (e.g., animal units/crop ha) because of extensive missing data. There were also cases where the model failed to converge due to a lack of variation. For example, it was not possible to have a commercial-gender interaction term due to the negligible number of female Amish farmers. Given the differences between the groups and the inability to compare machinery variables across groups, a separate regression with only commercial equine operators was developed, which included 79 responses.

\section{Results and Discussion}

Given the dearth of information available on these two populations of horse owners and the fact that this is the first study to compare them, an extensive examination of the descriptive statistics is presented, followed by the presentation of the regression results from combining both groups using a more restricted set of variables. An additional regression focusing on commercial operators was analyzed to focus on the effects of machinery.

\subsection{Summary Statistics}

Data relating to the demographic and general farm/operation characteristics are presented in Table 1 (values for categorical variables are either 1 -the respondent's answer corresponds to that category-or 0-it does not-so this is the range for these variables; one can usually interpret the mean of a categorical variable as the percentage of respondents in that column who are in that category). All differences discussed are significant unless otherwise indicated. Operators of commercial equine operations in Missouri are older than Amish farmers in Clark, Missouri. This finding of Amish farmers being younger on average was also found by Brock and Barham [27]. Commercial operators also have a higher level of education, with none having only an eighth grade education, as opposed to the Amish, of whom $88 \%$ had only an eighth grade education, in line with expectations. The majority of the commercial operators are female and the majority of the Amish operators are male.

Table 1. Summary statistics: operator demographic characteristics $(n=161)$.

\begin{tabular}{ccccc}
\hline \multirow{2}{*}{ Variables } & \multicolumn{4}{c}{ Mean Comparison } \\
\cline { 2 - 5 } & Range & Commercial & Amish & Difference $^{\text {a }}$ \\
\hline Age in years & & & & \\
$18-30$ & $0-1$ & 0.05 & 0.19 & $-0.14^{* *}$ \\
$31-45$ & $0-1$ & 0.18 & 0.52 & $-0.34^{* * *}$ \\
$46-60$ & $0-1$ & 0.44 & 0.21 & $0.23^{* *}$ \\
$61+$ & $0-1$ & 0.33 & 0.07 & $0.26^{* * *}$ \\
Education (highest level) & & & & $-0.88^{* * *}$ \\
8th grade & $0-1$ & 0 & 0.88 & -0.06 \\
High school & $0-1$ & 0.08 & 0.14 & $0.26^{* * *}$ \\
Some college & $0-1$ & 0.27 & 0.01 & $0.47^{* * *}$ \\
College graduate & $0-1$ & 0.47 & 0 & $0.14^{* * *}$ \\
Post-graduate degree & $0-1$ & 0.14 & 0 & $0.61^{* * *}$ \\
Gender & & & & $-0.62^{* * *}$ \\
Female & $0-1$ & 0.62 & 0.01 & \\
Male & $0-1$ & 0.37 & 0.99 &
\end{tabular}

${ }^{\mathrm{a}}$ Difference of means; ${ }^{* *}, 1 \% ;{ }^{* * *}, 0.1 \%$. 
Table 2 presents the operation characteristics. The majority (90\%) of the commercial equine operations are indeed professional, defined as breeding, training, boarding, selling, or recreation. The majority of the Amish operations (96\%) are utility operations (horses used for transportation or farm work). The percentage of total income from horse-related activities was $69 \%$ for the commercial operators and $21 \%$ for the Amish farmers, indicating that the Amish have more diversified operations. Commercial operations had more cropland, which was not in line with expectations. The average number of horses in the 226.8 to $499 \mathrm{~kg}$ range was higher in the commercial operations.

Table 2. Summary statistics: operation characteristics $(n=161)$.

\begin{tabular}{|c|c|c|c|c|}
\hline \multirow{2}{*}{ Variables } & \multicolumn{4}{|c|}{ Mean Comparison } \\
\hline & Range & Commercial & Amish & Difference $^{a}$ \\
\hline \multirow{2}{*}{\multicolumn{5}{|c|}{$\begin{array}{c}\text { Farm Operation } \\
\text { Type of horse operation }\end{array}$}} \\
\hline & & & & \\
\hline Hobby & $0-1$ & 0.09 & 0.01 & $0.08 *$ \\
\hline Utility (transportation or farming) & $0-1$ & 0.01 & 0.96 & $-0.95^{* * *}$ \\
\hline Professional (training, boarding, etc.) & $0-1$ & 0.90 & 0.10 & $0.80^{* * *}$ \\
\hline Horse-related income (\% of total income) & $0-100$ & 0.69 & 0.21 & $0.48^{* * *}$ \\
\hline \multicolumn{5}{|l|}{ Farm size } \\
\hline Hectares of pasture & 0-2023 & 48.12 & 16.37 & 31.86 \\
\hline Hectares of crop land & $0-73$ & 20.92 & 4.12 & $16.80^{* * *}$ \\
\hline \multicolumn{5}{|l|}{ Number of equines on farm } \\
\hline$<226.8 \mathrm{~kg}$ & $0-35$ & 4.57 & 4.17 & 0.40 \\
\hline $226.8-499 \mathrm{~kg}$ & $0-300$ & 26.94 & 4.63 & $22.31 * * *$ \\
\hline$>499 \mathrm{~kg}$ & 0-101 & 12.48 & 7.56 & $4.92 \#$ \\
\hline \multicolumn{5}{|l|}{ Bedding type used } \\
\hline Wood shavings & $0-1$ & 0.54 & 0.06 & $0.48^{* * *}$ \\
\hline Straw & $0-1$ & 0.06 & 0.74 & $-0.68^{* * *}$ \\
\hline Sawdust & $0-1$ & 0.52 & 0.52 & 0 \\
\hline \multicolumn{5}{|l|}{ Hay sources } \\
\hline Grow & $0-1$ & 0.16 & 0.37 & $-0.21^{* *}$ \\
\hline Purchase & $0-1$ & 0.59 & 0.11 & $0.48^{* * *}$ \\
\hline Grow and purchase & $0-1$ & 0.19 & 0.48 & $-0.29^{* * *}$ \\
\hline \multirow{2}{*}{\multicolumn{5}{|c|}{$\begin{array}{c}\text { Crop Production } \\
\text { Produced and marketed crops in } 2018\end{array}$}} \\
\hline & & & & \\
\hline Yes & $0-1$ & 0.08 & 0.63 & $-0.55^{* * *}$ \\
\hline No & $0-1$ & 0.68 & 0.21 & $0.47^{* * *}$ \\
\hline \multicolumn{5}{|l|}{ Crops produced } \\
\hline Corn & $0-1$ & 0.03 & 0.48 & $-0.45^{* * *}$ \\
\hline Soybeans & $0-1$ & 0.03 & 0.31 & $-0.28^{* * *}$ \\
\hline Wheat & $0-1$ & 0 & 0.09 & $-0.09 * *$ \\
\hline Barley or oats & $0-1$ & 0 & 0.27 & $-0.27^{* * *}$ \\
\hline Alfalfa or other hay & $0-1$ & 0.15 & 0.44 & $-0.29 * * *$ \\
\hline Vegetables & $0-1$ & 0.01 & 0.41 & $-0.40^{* * *}$ \\
\hline
\end{tabular}

${ }^{\text {a }}$ Difference of means; superscript ${ }^{\#}$ indicates $10 \%$ level of significance; ${ }^{*}, 5 \% ;{ }^{* *}, 1 \% ;{ }^{* * *}, 0.1 \%$.

The commercial equine operations were more likely than the Amish to use wood shavings as bedding and less likely to use straw. This may be because commercial operators would have to purchase bedding, and wood products are easier to clean from stalls. According to the review by Westendorf et al. [3], use of wood shavings and sawdust may result in a lower-quality manure product in commercial operations. The hay source for feeding the horses also varied between the types of operation. Commercial operators were more likely to have only purchased hay, while the Amish farmers were more likely to have grown their own or supplemented with purchased hay. The commercial operators are thus less likely to know how their hay was produced, especially since 
the Amish who do purchase hay are likely to purchase the hay locally from other Amish farmers in the Clark community. One problem with compost is that broadleaf herbicides from bedding, feed, or manure may kill plants on which it is applied $[37,38]$ so testing for residual herbicide may be required if forage was purchased [37].

Crop production for the market was much less common among commercial operators compared to the Amish. The Amish were more likely to have produced all the crops examined. This finding, as well as the lower percentage of income from horses, again indicates the diversified nature of Amish operations.

Commercial equine operations seldom apply manure or manure products to their crops; a maximum of $9 \%$ indicated that they sometimes applied composted manure to crops, which was significantly less than the Amish (Table 3). The survey did not ask about pasture application specifically. The most common application method for both groups was top-dressed application, which indicates that runoff of nutrients may be a problem [17].

Table 3. Summary statistics: manure application on cropland $(n=161)$.

\begin{tabular}{|c|c|c|c|c|}
\hline \multirow{2}{*}{ Variables } & \multicolumn{4}{|c|}{ Mean Comparison } \\
\hline & Range & Commercial & Amish & Difference $^{a}$ \\
\hline \multicolumn{5}{|c|}{$\begin{array}{l}\text { Manure Application Frequency on Cropland } \\
\text { Manure }\end{array}$} \\
\hline Always & $0-1$ & 0.04 & 0.25 & $-0.21^{* * *}$ \\
\hline Sometimes & $0-1$ & 0.05 & 0.43 & $-0.38^{* * *}$ \\
\hline Never & $0-1$ & 0.08 & 0 & $0.08 *$ \\
\hline \multicolumn{5}{|l|}{ Mature Manure } \\
\hline Always & $0-1$ & 0.03 & 0.01 & 0.02 \\
\hline Sometimes & $0-1$ & 0.06 & 0.35 & $-0.29^{* * *}$ \\
\hline Never & $0-1$ & 0.05 & 0.06 & -0.01 \\
\hline \multicolumn{5}{|l|}{ Compost } \\
\hline Always & $0-1$ & 0.03 & 0.01 & 0.02 \\
\hline Sometimes & $0-1$ & 0.09 & 0.26 & $-0.17^{* *}$ \\
\hline Never & $0-1$ & 0.06 & 0.11 & -0.05 \\
\hline \multicolumn{5}{|c|}{ Application Method } \\
\hline Top-Dressed & $0-1$ & 0.20 & 0.57 & $-0.37^{* * *}$ \\
\hline Tilled into soil & $0-1$ & 0.03 & 0.32 & $-0.29^{* * *}$ \\
\hline Other & $0-0$ & 0 & 0 & 0 \\
\hline
\end{tabular}

${ }^{\text {a }}$ Difference of means; $*, 5 \% ; * *, 1 \% ; * * *, 0.1 \%$.

There were distinct differences in manure management practices between the groups (Table 4). Commercial operations were significantly more likely to pile manure and compost than the Amish, while the Amish were more likely to spread the manure fresh over their fields, which implies that it may not be applied in the location and at the time when it is most needed. Westendorf et al. [3] indicate that horse manure storage has substantial environmental impacts.

Respondents were asked about their use of equipment and machinery for manure management. On the commercial side, the most frequently used equipment for manure management included tractors with buckets and power take-off (PTO)-drive manure spreaders, which can be used to pile and/or turn manure. As expected, none of the commercial operations used horse-drawn equipment, while $80 \%$ of the Amish did. Commercial operations were also less likely to use ground-drive manure spreaders. A reasonable inference from the data is that many Amish producers use horse-drawn ground-drive manure spreaders for their manure management, but do not have equipment that would facilitate piling and turning manure piles. Given that the Amish do not use tractors themselves, the comparison of means for that equipment is not indicated. 
Table 4. Summary statistics: manure management practices $(n=161)$.

\begin{tabular}{|c|c|c|c|c|}
\hline \multirow{2}{*}{ Variables } & \multicolumn{4}{|c|}{ Mean Comparison } \\
\hline & Range & Commercial & Amish & Difference $^{a}$ \\
\hline \multicolumn{5}{|l|}{$\begin{array}{c}\text { Manure Management Practices } \\
\text { On-farm manure management practices }\end{array}$} \\
\hline Piled & $0-1$ & 0.56 & 0.07 & $0.49^{* * *}$ \\
\hline Spread & $0-1$ & 0.34 & 0.85 & $-0.51^{* * *}$ \\
\hline Piled then spread later & $0-1$ & 0.30 & 0.19 & $0.11^{\#}$ \\
\hline Composted & $0-1$ & 0.34 & 0.02 & $0.32^{* * *}$ \\
\hline \multicolumn{5}{|l|}{$\begin{array}{c}\text { Machinery and Labor for Manure } \\
\text { Management }\end{array}$} \\
\hline No machinery or equipment & $0-1$ & 0.08 & 0.02 & 0.06 \\
\hline Horse-drawn equipment & $0-1$ & 0 & 0.80 & $-0.80 * * *$ \\
\hline Tractor with bucket & $0-1$ & 0.59 & 0 & $\mathrm{~b}$ \\
\hline Track loader or Bobcat & $0-1$ & 0.24 & 0 & $\mathrm{~b}$ \\
\hline Manure spreader with ground drive & $0-1$ & 0.27 & 0.78 & $-0.51^{* * *}$ \\
\hline Manure spreader with PTO drive & $0-1$ & 0.30 & 0 & $\mathrm{~b}$ \\
\hline Other & $0-1$ & 0.15 & 0.02 & $0.13^{* *}$ \\
\hline \multicolumn{5}{|l|}{$\begin{array}{c}\text { Number of people responsible for manure } \\
\text { management }\end{array}$} \\
\hline Primary operators & $0-9$ & 1.78 & 1.47 & 0.31 \\
\hline Horse boarders & $0-38$ & 11.8 & 0 & $11.80 *$ \\
\hline Hired laborers & $0-14$ & 3.74 & 1.00 & $2.74^{* * *}$ \\
\hline Unpaid volunteers or family members & $0-10$ & 2.42 & 2.44 & -0.02 \\
\hline \multicolumn{5}{|l|}{$\begin{array}{l}\text { Hours per week spent on manure management } \\
\text { (total) }\end{array}$} \\
\hline $0-3$ & $0-1$ & 0.22 & 0.57 & $-0.35^{* * *}$ \\
\hline $3-6$ & $0-1$ & 0.04 & 0.09 & $-0.05 *$ \\
\hline $6-10$ & $0-1$ & 0.20 & 0.17 & $0.03^{* *}$ \\
\hline $10+$ & $0-1$ & 0.52 & 0.02 & $0.50^{* * *}$ \\
\hline
\end{tabular}

${ }^{a}$ Difference of means; superscript ${ }^{\#}$ indicates $10 \%$ level of significance; ${ }^{*}, 5 \% ;{ }^{* *}, 1 \%$; ${ }^{* * *}, 0.1 \% .{ }^{b}$ Comparison of means is inappropriate since the Amish do not use tractors.

Manure management can be a time-consuming and unpleasant task. Respondents were asked how many people were responsible for manure management each week, as well as about the roles of those people. The number of people involved did not take account of how much time they spent on manure management, i.e., it is not a full-time equivalent measure. Commercial operations were more likely than the Amish to indicate that manure management was done by horse boarders and hired laborers. Respondents were also asked about how much time each week was spent on manure management by all those involved. The most common category for commercial operators was over $10 \mathrm{~h}$, while the most common category for the Amish was $0-3 \mathrm{~h}$, and these differences were highly significant.

Sources of information on manure management also differed between groups (Table 5). The most common source indicated by commercial equine operations was the internet, while no Amish indicated that that was a source for them. Commercial operations were also more likely than the Amish to use other horse owners, government agencies, University Extension Services, and magazines, while the Amish were more likely to use other farmers as well as family and community members. These results imply that educational efforts may need to be designed differently for the two groups; programming could be online for commercial operators and via mailed documents or local in-person meetings for the Amish. An encouraging finding is that the majorities of both groups would like to receive more information about manure management practices, and this is significantly higher for commercial operation. 
Table 5. Summary statistics: manure management knowledge and attitudes.

\begin{tabular}{|c|c|c|c|c|}
\hline \multirow{2}{*}{ Variables } & \multicolumn{4}{|c|}{ Mean Comparison } \\
\hline & Range & Commercial & Amish & Difference $^{a}$ \\
\hline \multicolumn{5}{|l|}{$\begin{array}{l}\text { Information sources about manure } \\
\text { management }\end{array}$} \\
\hline Previous employment & $0-1$ & 0.13 & 0.07 & 0.06 \\
\hline Other horse owners & $0-1$ & 0.29 & 0.17 & $0.12^{\#}$ \\
\hline Other farmers & $0-1$ & 0.30 & 0.44 & $-0.14^{\#}$ \\
\hline Government agencies & $0-1$ & 0.09 & 0 & $0.09 * *$ \\
\hline University Extension Services & $0-1$ & 0.25 & 0.10 & 0.15 * \\
\hline Internet & $0-1$ & 0.41 & 0 & $0.41^{* * *}$ \\
\hline Magazines or newspapers & $0-1$ & 0.20 & 0.10 & $0.10^{\#}$ \\
\hline Family, neighbors, community members & $0-1$ & 0.27 & 0.52 & $-0.25^{* * *}$ \\
\hline Other & $0-1$ & 0.10 & 0.09 & 0.01 \\
\hline \multicolumn{5}{|l|}{$\begin{array}{l}\text { Want more information on improved manure } \\
\text { practices }\end{array}$} \\
\hline Yes & $0-1$ & 0.72 & 0.51 & $0.21 * *$ \\
\hline No & $0-1$ & 0.22 & 0.31 & -0.09 \\
\hline \multicolumn{5}{|l|}{ Motivation for composting manure } \\
\hline Protecting soil health & $0-1$ & 0.37 & 0.21 & $0.16^{*}$ \\
\hline Protecting water quality & $0-1$ & 0.24 & 0.04 & $0.20 * * *$ \\
\hline Income opportunities & $0-1$ & 0.13 & 0.07 & 0.06 \\
\hline \multicolumn{5}{|l|}{ Laboratory tested for chemical composition } \\
\hline Never tested & $0-1$ & 0.86 & 0.56 & $0.30^{* * *}$ \\
\hline Tested manure & $0-1$ & 0.01 & 0 & 0.01 \\
\hline Tested compost & $0-1$ & 0.01 & 0 & 0.01 \\
\hline Tested soil & $0-1$ & 0.10 & 0.42 & $-0.32 * * *$ \\
\hline \multicolumn{5}{|l|}{$\begin{array}{c}\text { Sold, bartered, or traded manure or manure } \\
\text { products }\end{array}$} \\
\hline Yes & $0-1$ & 0.37 & 0.02 & $0.35^{* * *}$ \\
\hline No & $0-1$ & 0.54 & 0.88 & $-0.34^{* * *}$ \\
\hline \multicolumn{5}{|l|}{$\begin{array}{l}\text { If you haven't sold manure or compost, why } \\
\text { not? }\end{array}$} \\
\hline Use it for agriculture & $0-1$ & 0.28 & 0.94 & $-0.66^{* * *}$ \\
\hline Didn't know it is an option & $0-1$ & 0.09 & 0.10 & -0.01 \\
\hline Too much time to compost & $0-1$ & 0.08 & 0.02 & 0.06 \\
\hline Too much time to find buyer & $0-1$ & 0.13 & 0.01 & $0.12 * *$ \\
\hline Don't know how to compost & $0-1$ & 0.11 & 0.09 & 0.02 \\
\hline Too busy with other activities & $0-1$ & 0.27 & 0.21 & 0.06 \\
\hline No place to compost & $0-1$ & 0.06 & 0.10 & -0.04 \\
\hline No equipment to compost & $0-1$ & 0.19 & 0.27 & -0.08 \\
\hline Other & $0-1$ & 0.13 & 0.01 & $0.12 * *$ \\
\hline \multicolumn{5}{|l|}{$\begin{array}{c}\text { Manure management practices impact water } \\
\text { quality }\end{array}$} \\
\hline Strongly agree & $0-1$ & 0.42 & 0.09 & $0.33^{* * *}$ \\
\hline Agree & $0-1$ & 0.38 & 0.38 & 0 \\
\hline Neither agree nor disagree & $0-1$ & 0.11 & 0.11 & 0 \\
\hline Disagree & $0-1$ & 0 & 0.01 & -0.01 \\
\hline Strongly disagree & $0-1$ & 0 & 0.03 & $-0.03^{\#}$ \\
\hline Don't know (need more information) & $0-1$ & 0.08 & 0.27 & $-0.19^{* * *}$ \\
\hline
\end{tabular}

${ }^{a}$ Difference of Means; superscript ${ }^{\#}$ indicates $10 \%$ level of significance; ${ }^{*}, 5 \% ;{ }^{* *}, 1 \%$; ${ }^{* * *}, 0.1 \%$.

For those that do compost manure, protecting soil health was the most important reason indicated by both commercial operations and the Amish, but was significantly higher for the commercial operations. This group was also more likely to indicate that protecting water quality was a reason for composting. Commercial operations were more likely to have never tested manure, compost, or soil for nutrient content. The Amish were more likely to have tested their soil for nutrients in the 
past, indicating that they are aware of crop nutrient needs (in Missouri, standard soil tests include $\mathrm{pH}$, organic matter, phosphorous, potassium, calcium, and magnesium, but do not include nitrogen). Testing rates for manure and compost were very low for both groups, similarly to other research findings that indicate that soil is more likely to be tested than manure, even though testing of manure enables application in line with crop requirements (e.g., [16]).

A major research question was whether these groups sold or bartered manure products, as well as to identify the barriers for those who did not in order to determine the potential for value-added manure products. Commercial equine operators were more likely to market manure products than the Amish. Among those who had not sold manure or compost, the most common reason for the commercial group was that they use it for agriculture or that they are too busy with other activities, followed by a lack of equipment for composting. These were also the most important reasons for the Amish; however, the Amish were significantly more likely to indicate that they use it for agriculture. One reason that was more important for commercial operators was that it took too much time to find buyers. About $10 \%$ of both groups had not thought of selling manure or compost as an option; a similar percentage indicated that they did not know how to compost, and there were no significant differences between the means. Given that commercial operators have a higher likelihood of piling manure and of possessing the necessary equipment, targeting educational efforts regarding value-added manure products towards this group may be appropriate.

One question asked the level of agreement with the statement "Manure management practices impact water quality." The majority of the commercial respondents indicated that they agreed or strongly agreed, significantly more than the Amish respondents. This is in line with some previous research on the Amish [30,39]. Commercial respondents were less likely to indicate that they did not know whether there were impacts.

\subsection{Regression Results for Determinants of Manure Sales/Transfers: Commercial and Amish}

As expected, commercial horse operations were significantly more likely to have sold manure or compost compared to Amish farmers, partly due to the latter's use of horse manure in crop production, as discussed earlier (Table 6). Men were less likely to have sold manure or compost than women. If manure was composted, rather than being spread immediately over the fields, it was more likely that the operator sold manure or compost. As indicated above, this is potentially a more valuable product that is easier to transport. For the variables relating to the impact of manure management on water quality, those who were neutral or said they did not know were more likely to have sold manure than those who agreed or strongly agreed. The implication is not that we should reduce understanding of the impact of manure on water quality to increase manure sales, but rather that those who sell manure may know less about manure in general. The results were robust to alternative specifications of the model. Robustness checks with age, animal units rather than the log of that measure, the presence of a tractor with bucket, the number of people responsible for manure management, and soil testing alone did not change the variables that were significant in the model.

\subsection{Regression Results for Determinants of Manure Sales/Transfers: Commercial Group}

In order to examine the effect of equipment in greater depth, a separate logistic regression was analyzed for only commercial operations (Table 7). The same bivariate regression response variable (sales/transfers of manure products) and base (no sales of manure products) were used as in the combined Amish and commercial group regression (a regression attempting to use the same or similar variables for the Amish group was attempted, but was unable to converge due to the lack of variation in the survey responses). No correlation coefficients exceeded $|0.33|$. The significant variables in the combined regression were also significant for only commercial operators. The model fit statistics were slightly better. Among the commercial respondents, male managers were more likely to sell manure or composted manure products than female managers. The number of horses at the facility was not a predictor, as the natural log on animal units was not a significant variable, nor were having marketed 
crops or only having draft horses. Composting manure had a positive and significant relationship with selling manure products relative to those who spread manure immediately on fields.

Table 6. Results of logistic regression for the sale/transfer of manure or compost by all respondents $(n=160)$.

\begin{tabular}{|c|c|c|}
\hline Independent Variables & Coefficients $^{a}$ & $\mathrm{SE}^{\mathrm{b}}$ \\
\hline \multicolumn{3}{|l|}{ Farm and farmer characteristics } \\
\hline Commercial (base $=$ Amish) & $2.77 *$ & 1.11 \\
\hline Male (base $=$ female) & $-1.10^{\#}$ & 0.58 \\
\hline Ln animal units & 0.27 & 0.28 \\
\hline Marketed crops in 2018 (base $=$ no) & -0.36 & 0.86 \\
\hline \multicolumn{3}{|l|}{ Manure Management } \\
\hline Manure is piled (base = spread immediately) & 0.06 & 0.53 \\
\hline Piled then spread over fields & 0.12 & 0.56 \\
\hline Manure is composted & $1.27 *$ & 0.56 \\
\hline More than $3 \mathrm{~h}$ per week spent on manure management $($ base $<3$ ) & -0.07 & 0.65 \\
\hline Tested soil, manure, or compost for nutrient content (base $=$ no) & -0.27 & 0.80 \\
\hline \multicolumn{3}{|l|}{ Manure management practices impact water quality } \\
\hline Disagree/strongly disagree (base $=$ Agree/strongly agree) & -3.26 & 23.58 \\
\hline Neither Agree/Disagree & $1.88^{*}$ & 0.78 \\
\hline Do not know & $1.64 *$ & 0.84 \\
\hline Intercept & $-4.62 * * *$ & 1.37 \\
\hline \multicolumn{3}{|l|}{ Goodness of Fit } \\
\hline AIC & 130.90 & \\
\hline Nagelkerke R2 & 0.45 & \\
\hline LR Chi2 & 52.42 & \\
\hline
\end{tabular}

${ }^{a}$ Note: Superscript ${ }^{\#}$ indicates $10 \%$ level of significance; ${ }^{*}, 5 \% ;{ }^{* *}, 1 \% ;{ }^{* * *}, 0.1 \%$. ${ }^{b}$ Standard Error.

Table 7. Results of logistic regression for sale of manure or compost by commercial facilities $(n=79)$.

\begin{tabular}{|c|c|c|}
\hline Independent Variables & Coefficients $^{a}$ & $\mathrm{SE}^{\mathrm{b}}$ \\
\hline \multicolumn{3}{|l|}{ Farm and farmer characteristics } \\
\hline Male (base $=$ female) & $-2.19 *$ & 0.86 \\
\hline Ln animal units & 0.60 & 0.15 \\
\hline Marketed crops in 2018 (base $=$ no) & -1.99 & 1.59 \\
\hline Only draft horse operation & -1.44 & 1.48 \\
\hline \multicolumn{3}{|l|}{ Manure Management } \\
\hline Manure is piled (base, spread immediately) & 0.06 & 0.53 \\
\hline Piled then spread over fields & 0.12 & 0.56 \\
\hline Manure is composted & $1.27 *$ & 0.56 \\
\hline Only machinery to pile, turn and load (base, other machinery) & $-1.96^{* *}$ & 0.97 \\
\hline No machinery is used & 0.70 & 1.27 \\
\hline More than $3 \mathrm{~h}$ per week spent on manure management (base $<3$ ) & -0.07 & 0.65 \\
\hline Only hired laborers are responsible for manure management & 0.55 & 0.94 \\
\hline Tested soil, manure, or compost for nutrient content (base $=$ no) & -0.27 & 0.80 \\
\hline \multicolumn{3}{|l|}{ Manure management practices impact water quality } \\
\hline Disagree/Strongly Disagree $($ base $=$ Agree/Strongly Agree) & -2.27 & 0.92 \\
\hline Neither Agree/Disagree & $4.62 * *$ & 1.49 \\
\hline Do not know & $3.80 * *$ & 0.78 \\
\hline Intercept & -2.10 & 1.58 \\
\hline \multicolumn{3}{|l|}{ Goodness of Fit } \\
\hline AIC & 100.22 & \\
\hline Nagelkerke R2 & 0.47 & \\
\hline LR Chi2 & 33.65 & \\
\hline
\end{tabular}

\footnotetext{
${ }^{a}$ Note: superscript ${ }^{\#}$ indicates $10 \%$ level of significance; ${ }^{*}, 5 \% ; * *, 1 \% ; * * *, 0.1 \%$. ${ }^{\text {b }}$ Standard error.
} 
For this regression, categorical variables related to machinery were created as indicated in the methods section. Those with only access to equipment that would pile, turn, and load manure (versus having other equipment related to spreading) had a significant negative relationship with selling compost. This seems counter-intuitive to the expectation that the presence of equipment needed for composting would have a positive relationship with selling, as composting (versus spreading immediately) has a positive relationship. One possible explanation that could be explored in future research is that facilities sell manure or compost (letting the buyers load/transport) because they are ill-equipped to handle it in any other way. All those who sold manure products indicated that the buyers hauled it, while $18 \%$ also indicated separate haulers, and only $11 \%$ also indicated horse owners (data not shown). If this is because the sellers lack the necessary equipment, a third-party manure recycler would be of even greater value to commercial equine managers.

Variables testing the intensity of manure management, i.e., time spent on manure management and whether employees were the only people responsible for manure management, did not have a significant relationship to manure marketing activities, nor did nutrient testing.

The same question regarding whether manure management has impacts on water quality was included in the commercial-only regression. The base was "agree"/"strongly agree". There were no commercial responses for "disagree"/"strongly disagree", so that variable was not included in the regression. Those who responded "neither agree nor disagree" and "I do not know" were significantly more likely to have sold manure or compost compared to those who indicated that they agreed that manure impacts water quality.

\section{Conclusions and Implications}

Sustainable utilization of manure, including horse manure, depends on recycling valuable components while reducing negative impacts on the environment [1]. Moving towards this goal requires an understanding of the motivations and behavior of those managing the manure in order to design tailored educational efforts. This study contributed to a better understanding of manure management by two distinct groups of horse owners, which can enable educators to tailor their efforts.

From the examination of the summary statistics, commercial equine operations in Missouri differ fundamentally from Amish farmers who use horses for traction and transportation. They differ in the number of horses, uses of manure, manure storage, equipment for manure management, information sources, environmental attitudes, and the likelihood of selling manure or compost. There are also some similarities, such as low levels of nutrient testing of manure and compost and a desire for more information on best management practices for manure. Both of these groups are underserved by the typical channels used to reach other livestock managers.

These results imply that effective educational efforts to reduce negative environmental impacts of horse manure and capture soil amendment value will take into account these differences. There is evidence that commercial managers are less likely than the Amish to view manure as a valuable nutrient resource, but through targeted education efforts, they could be encouraged to view it as a value-added product. Providing education about proper composting techniques could improve their current manure management practices and increase the likelihood that they engage in marketing activities. Another implication is that reducing transaction costs in finding buyers for their manure, such as the creation of local internet-based information exchanges on manure product availability, could facilitate manure markets. Markets are likely to be localized due to the volume and weight of manure relative to the nutrient content. There may be an opportunity for intermediaries to collect or purchase manure, compost it, and then retail the value-added product. Because the major source of manure management information for this group is the internet, educational programs need to focus on that medium. Since they realize that manure management affects water quality, these programs should also explain the environmental benefits of improved management practices.

Implications from the research for educational programs oriented towards the Amish differ from those for commercial equine operations. Extension personnel could work with Amish producers 
within their cultural context to develop methods of utilizing manure nutrients most efficiently on farms. For example, due to the de-emphasis on formal education and because English is typically a second language for the Amish (it is the language of instruction in their schools), extension materials should target resources to the eighth grade reading level. It is also helpful to work with local leaders within the community to help distribute written material and/or to organize workshops.

Complementary research to this study could evaluate the demand for horse manure in order to provide information to producers on the desired attributes of manure products and realistic estimates of prices that consumers would be willing to pay. Detailed examination of composting technologies for smaller farms in the USA's Midwest would be useful in determining the feasibility under alternative circumstances. In addition, equine operators in Missouri may differ from those in other regions, which means that studies in other areas are needed. Old-Order Amish are also diverse and locally organized, so the results may not transfer to other groups or other regions $[31,32]$.

Author Contributions: Conceptualization, J.D. and L.M.; Data curation, J.D.; Formal analysis, J.D.; Funding acquisition, J.D. and L.M.; Methodology, C.M.; Project administration, L.M.; Resources, C.B.; Supervision, L.M.; Writing—original draft, J.D. and L.M.; Writing—review \& editing, J.D., L.M. and C.B. All authors have read and agreed to the published version of the manuscript.

Funding: We acknowledge funding from the Missouri Agricultural Experiment Station and the Dudley and Virgie Alexander Scholarship fund, College of Agriculture, Food and Natural Resources, University of Missouri.

Conflicts of Interest: The authors declare no conflict of interest.

\section{References}

1. He, Z.; Pagliari, P.; Waldrip, H.M. Advances and outlook of manure production and management. In Animal Manure: Production, Characteristics, Environmental Concerns and Management; Waldrip, H.M., Pagliari, P.H., He, Z., Eds.; ASA and SSSA: Madison, WI, USA, 2020; pp. 373-383.

2. Waldrip, H.M.; Pagliari, P.H.; He, Z. Animal Manure: Production, Characteristics, Environmental Concerns and Management. ASA Spec. Publ. 2019, 67, 430.

3. Westendorf, M.L.; Williams, C.A.; Murphy, S.; Kenny, L.; Hashemi, M. Generation and management of manure from horses and other equids. In Animal Manure: Production, Characteristics, Environmental Concerns and Management; Waldrip, H.M., Pagliari, P.H., He, Z., Eds.; American Society of Agronomy: Madison, WI, USA, 2019; pp. 145-163.

4. USDA-APHIS 2017. Available online: https://www.aphis.usda.gov/animal_health/nahms/equine/downloads/ equine15/Eq2015_Rept2_1.pdf (accessed on 23 February 2020).

5. USDA-APHIS 2017. Available online: https://www.aphis.usda.gov/animal_health/nahms/equine/downloads/ equine15/Equine15_is_Demographics.pdf (accessed on 23 February 2020).

6. Donnermeyer, J.F.; Anderson, C.; Cooksey, E.C. The Amish population: County estimates and settlement patterns. J. Amish Plain Anabapt. Stud. 2013, 1, 72-109. [CrossRef]

7. Perry-Hill, R.; Prokopy, L. Improving environmental management on small-scale farms: Perspectives of extension educators and horse farm operators. Environ. Manag. 2015, 55, 31-42. [CrossRef]

8. Yuan, Y.; Locke, M.A.; Bingner, R.L.; Rebich, R.A. Phosphorus losses from agricultural watersheds in the Mississippi Delta. J. Environ. Manag. 2013, 115, 14-20. [CrossRef]

9. Kleinman, P. Managing Manure for Sustainable Livestock Production in the Chesapeake Bay Watershed. J. Soil Water Conserv. 2012, 7, 54A-61A. [CrossRef]

10. Hoag, D.L.; Lacy, M.G.; Davis, J. Pressures and Preferences Affecting Willingness to Apply Beef Manure on Crops in the Colorado High Plains. J. Agric. Resour. Econ. 2004, 29, 461-480.

11. Pennsylvania State University Extension. Horse Stable Manure Management. Available online: https: //extension.psu.edu/horse-stable-manure-management (accessed on 12 November 2018).

12. Chastain, J.P.; Moore, K.P. Plant Nutrient and Carbon Content of Equine Manure as Influenced by Stall Management in South Carolina. Available online: https:/www.clemson.edu/extension/camm/manuals/ publications/equine_manure_and_stall_mgt.pdf (accessed on 22 June 2020). 
13. Conners, S.E.; Couetil, L.; Furdek, J.M.; Russell, M.A.; Angriawan, A.; Ruth, D. Indiana Equine Industry Economic Impact and Health Study. Purdue Calumet Equine Program; Purdue University: Hammond, IN, USA, 2011; Available online: https://vet.purdue.edu/esmc/files/documents/Indiana-Equine-Industry-EconomicImpact-and-Health-Study-2011.pdf (accessed on 15 May 2019).

14. Westendorf, M.L.; Joshua, T.; Komar, S.J.; Williams, C.; Govindasamy, R. Manure Management Practices on New Jersey Equine Farms. Prof. Anim. Sci. 2010, 26, 123-129. [CrossRef]

15. Young Center for Anabaptist and Pietist Studies. Amish Population, 2019; Elizabethtown College: Elizabethtown, PA, USA, 2019; Available online: http://groups.etown.edu/amishstudies/statistics/population2019/ (accessed on 23 June 2020).

16. Ali, S.; McCann, L.; Allspach, J. Manure Transfers in the Midwest and Factors Affecting Adoption of Manure Testing. J. Agric. Appl. Econ. 2012, 44, 533-548. [CrossRef]

17. Ribaudo, M.; Gollehon, N.; Aillery, M.; Kaplan, J.; Johansson, R.; Agapoff, J.; Christensen, L.; Breneman, V.; Peters, M. Manure Management for Water Quality: Costs to Animal Feeding Operations of Applying Manure Nutrients to Lands; U.S. Department of Agriculture, Economic Research Service: Washington, DC, USA, 2003.

18. Hoag, D.L.; Roka, F.M. Environmental Policy and Swine Manure Management: Waste Not or Want Not. Am. J. Altern. Agric. 1995, 10, 163-166. [CrossRef]

19. McCann, L.; Abdalla, C.; Jenner, M.; Massey, R. Improved Manure Management and Utilization: A Systems Approach. Renew. Agric. Food Syst. 2005, 20, 127-135. [CrossRef]

20. Vertical, I.Q. Horse Farming Industry Trends. Available online: https://app.verticaliq.com/industries/365horse-farming/sections/8 (accessed on 19 February 2020).

21. Norwood, F.; Luter, R.; Massey, R. Asymmetric Willingness-to-Pay Distributions for Livestock Manure. J. Agric. Resour. Econ. 2005, 30, 431-448.

22. Bogardus, M. Markets for Composted Agricultural Waste, Livestock and Poultry Environmental Learning Community. 2019. Available online: https://lpelc.org/markets-for-composted-agricultural-waste (accessed on 1 March 2020).

23. Cross, J.A. Change and sustainability issues in America's Dairyland. Focus Geogr. 2015, 58, 173-183. [CrossRef]

24. Kraybill, D.; Johnson-Weiner, K.; Nolt, S. The Amish; The John Hopkins University Press: Baltimore, MD, USA, 2013; p. 282.

25. Correll, E. The Mennonite agricultural model in the German Palatinate. Pa. Mennon. Herit. 1991, 14, 7.

26. McConnell, D.; Loveless, M. Nature and the Environment in Amish Life; John Hopkins University Press: Baltimore, MD, USA, 2018.

27. Brock, C.; Barham, B. Farm structural change of a different kind: Alternative dairy farms in Wisconsin-graziers, organic and Amish. Renew. Agric. Food Syst. 2009, 24, 25-37. [CrossRef]

28. Park, K. Interpreting Non-Amish Perceptions of the Old Order Amish Using Cultural Relativism and Human Rights Frameworks. J. Amish Plain Anabapt. Stud. 2018, 6, 117-143. [CrossRef]

29. Kogelmann, W.J.; Bryant, R.B.; Lin, H.S.; Beegle, D.B.; Weld, J.L. Local assessments of the impacts of phosphorus index implementation in Pennsylvania. J. Soil Water Conserv. 2006, 61, 20-30.

30. Ulrich-Schad, J.D.; Brock, C.; Prokopy, L.S. A Comparison of Awareness, Attitudes, and Usage of Water Quality Conservation Practices Between Amish and Non-Amish Farmers. Soc. Nat. Resour. 2017, 30, 1-15. [CrossRef]

31. Brock, C.; Ulrich-Schad, J.D.; Prokopy, L. Bridging the Divide: Challenges and Opportunities for Public Sector Agricultural Professionals Working with Amish and Mennonite Producers on Conservation. Environ. Manag. 2018, 61, 756-777. [CrossRef] [PubMed]

32. Parker, J.S. Integrating culture and community into environmental policy: Community tradition and farm size in conservation decision making. Agric. Hum. Values 2013, 30, 159-178. [CrossRef]

33. Bergefurd, B. Assessing Extension Needs of Ohio's Amish and Mennonite Produce Auction Farmers. Master's Thesis, Ohio State University, Columbus, OH, USA, 2011.

34. Yoder, L. The Amish of Missouri 2016 Directory; Pilgrim Boom Printing: Medina, NY, USA, 2016.

35. Dillman, D.A.; Smyth, J.D.; Christian, L.M. Internet, Phone, Mail, and Mixed-Mode Surveys: The Tailored Design Method, 4th ed.; John Wiley: Hoboken, NJ, USA, 2014.

36. Manske, L. Animal Unit Equivalent for Beef Cattle Based on Metabolic Weight. North Dakota State University Extension, 1998. Available online: https://extension.umd.edu/sites/extension.umd.edu/files/_docs/programs/ 4-H/AnimalSciences/WSU_draft_horse_handbook.pdf (accessed on 17 May 2019). 
37. Trinklein, D. Contaminated Compost Equals Gardening Problems. University of Missouri Division of Plant Sciences, 2014. Available online: https://ipm.missouri.edu/meg/2014/8/Contaminated-Compost-EqualsGardening-Problems/ (accessed on 24 March 2019).

38. Daughtry, M. Herbicide Carryover in Hay, Manure, Compost and Grass Clippings. North Carolina Cooperative Extension, 2016. Available online: https://lee.ces.ncsu.edu/2016/03/herbicide-carryover-in-haymanure-compost-and-grass-clippings/ (accessed on 3 March 2020).

39. Widner, D.E. Old Order Amish Beliefs about Environmental Protection and the Use of Best Management Practices in the Sugar Creek Watershed. Master's Thesis, Kent State University, Kent, OH, USA.

Publisher's Note: MDPI stays neutral with regard to jurisdictional claims in published maps and institutional affiliations.

(C) 2020 by the authors. Licensee MDPI, Basel, Switzerland. This article is an open access article distributed under the terms and conditions of the Creative Commons Attribution (CC BY) license (http://creativecommons.org/licenses/by/4.0/). 